\title{
THE EFFECT OF USING COMPUTER ASSISTED LANGUAGE LEARNING (CALL) METHOD ON STUDENTS' LISTENING SKILL AT THE SEVENTH GRADE STUDENTS OF SMP NEGERI 3 STABAT
}

\author{
Ika Lestari1, Ummi umara ${ }^{2}$ \\ STKIP BUDIDAYA BINJAI
}

\begin{abstract}
Applying an appropriate teaching method plays an important role in the teaching or learning process including teaching listening as a skill. The listening skill is one of the four most important and difficult skill to be taught in English. Students are facing a difficulty either in understanding native speaker or in producing native-like English (accent/pronunciation). They are also unprepared to function in the new word. And then, in most class students are unmotivated and act as passive listeners. This study aimed to find out whether using computer assisted language learning (CALL) method affect listening skill. In this study, using computer assisted language learning (call) method as the independent variable (X) and students' listening skill as the dependent variable (Y), with the hypothesis: using computer assisted language learning (CALL) method affects on students' listening skill of seventh year students of SMP NEGERI 3 STABAT at academic year 2018/2019. The population of this study was seventh year students of SMP NEGERI 3 STABAT at academic year 2018/2019, which consisted of 185 students. The sample was taken by using random sampling technique, the total sample was 60 students. Then, the sample was divided into two groups, the group taught by using computer assisted language learning (CALL) was as the experimental group and the group taught without computer assisted language learning (CALL) was as the control group. The writer used test as the instrument of collecting data. The data was analyzed by using t-test formula. Based on the data analysis, it was found that the value of $t$-observed $\left(\mathrm{t}_{\mathrm{o}}\right)$ was higher than the value of $\mathrm{t}$-table, $\left(\mathrm{t}_{\text {observed }}=8,39>\mathrm{t}_{\text {table }}=1.67\right)$. Therefore, the hypothesis proposed by the writer was accepted. In the other words, using computer assisted language learning (CALL) affects listening skill of seventh year students of SMP NEGERI 3 STABAT at academic year 2018/2019.
\end{abstract}

Keywords: Computer Assisted Language Learning (CALL), Listening Skill 


\section{INTRODUCTION}

English is regarded as international language. It means that it plays as an important role in international communication. It serves people as a bridge into the worlds of higher education, economics, culture, science, technology, politics, international trade, et cetera. In Indonesia, English as a foreign language to be teach at school, English is give to students of elementary school until university. The aims of mastering English are to develop Indonesian people in international trade and maintain good relationship with other countries. In learning English, there are four major skills to be learnt. They are listening, speaking, reading, and writing. Among four language skills, listening has more attention from teacher and learners in language teaching (Siegel, Joseph 2015). Listening also has great importance in foreign language classroom.

In language learning process, listening provides input to students. If the students are unable to understand the input, the learning process is unable to begin (Rost, M. 1994). Listening is an activity to get the important information as first input for students. As Sharma states that listening provides the aural input that serves the basic for language acquisition and enable learners to interact in speak communication. Listening becomes the indicator of someone's knowledge in a language (Sharma, Neena. 2011)

Before people learn to speak English, they shall understand what they heard. It means that all of people must be mastered listening for the first. Without learning listening earlier, the learners are unable to speak the target language. In fact, many students have minimum listening proficiency and lack in vocabulary mastery.
Students encounter difficulties that come from sound, words, classifying words, and sentences.

The students also have problem with interpretation such as categorizing new information or seeing cause and effect relationship between facts. Therefore, teacher should actively explore the nature and process of listening comprehension in order to improve listening teaching outcomes and make students recognize that listening comprehension is the crucial aspect of English learning.

In this study, the researcher introduces a method to teach listening which used computer as an aid to the presentation, reinforcement, and assessment material. It represents challenge for the teacher and for students as a new medium of exploration, namely Computer Assisted Language Learning (CALL). Computer Assisted Language Learning (CALL) refers to any process in which the learner uses a computer to improve foreign language competence.

CALL provides drills and practice to students. In this phase, the computer is used as tutor, presenting drill exercises without feedback component. It gives students choices, control, and interaction. CALL based on multimedia computers and the internet that combine text, graphics, sound, animation, and video.

According to Nachoua, the use of CALL (Computer Assisted Language Learning) is effective method to enhance students' motivation hence their performance in listening (2012). Students are preparing to face a difficulty in understanding native speaker's accent or pronunciation. In the most classes also motivate and act as active listeners. The students who learn listening skill using CALL reflect good scores and active listener in motivate classes because they were not just expose to an aural environment but also a visual one. Therefore, 
CALL is a motivating method and computers are worthwhile tools to be use in foreign language classes to develop students' listening skill.

\section{REVIEW OF THE RELATED LITERATURE}

When Communicative Language Teaching (CLT) appeared in the 1970s and 1980 s as a new approach to language teaching, the notion of communicative competence was developed and it was argued that the goal of language teaching should be communicative competence (Richards, 2006). Communicative competence, the ability to use language correctly and appropriately, can be acquired through the four skills. Among these four skills, listening plays a key role in communicative competence. It should receive special attention in the process of language learning. Listening must be taught and practiced as a crucial component of communicative competence.

\section{Listening Skill}

Listening is a combination of hearing what another people said and psychological involvement with the person who is talking (Tyagi, Babita. 2013). This includes the understanding of someone's accent and pronunciation, his vocabulary and grammar, and catching his meaning. Thus, Rost states listening is a process of receiving what the speaker actually says; constructing and representing meaning; negotiating meaning with the speaker and responding; and creating meaning through involvement, imagination and empathy (2002).

Based on the definitions above, it can be concluded that listening is a combination of hearing what speaker said and psychological involvement to understand someone's speech with selection and interpretation information from auditory and visual clues. Aspects of listening include speech perception, word recognition, sentence processing, construct the literal meaning of sentence, hold the information, infer the implied meaning and intention, predict what is to be said, and decide how to respond.

\section{Teaching Listening}

Teaching can be defined as helping someone to learn how to do something, giving instruction, guiding in certain study, providing with knowledge, causing to know or understand. As Brown states that teaching is guiding and facilitating learning, enabling to learner to learn, setting the condition for learning (Brown, HD. 2007). It means that teaching provides us to understand how to learn will determine the philosophy of education, teaching style, approach, methods and classroom approach.

Siahaan also states that teaching is the way an instruction is organized, how much the students are involved actively in learning, how much the students are responsible for the learning, and how learning is assessed (Siahaan, Sanggam. 2008). Meanwhile, Sharma states that listening is a communication method that requires the listener to understand, interpret, and assess what they hear (Sharma, Neena. 2011). So, it can be concluded that teaching listening is helping listener with guiding and facilitating learning in order to the listener understand to interpret and assess what they hear.

\section{CALL (Computer-Assisted Language Learning)}

Computer Assisted Language Learning (CALL) refers to any process in which the learner uses a computer to improve foreign language competence. CALL includes the sets of 
instructions which need to be loaded into the computer for it to be able to work in the language classroom Futher, Morales also states that CALL is a method that used computers or electronic devices to teach or learn a language. Devices are used as tools to promote and enhance the learning of language. The devices include smart phones, tablets, MP3 players, and et ceter (Morales, Nelson E. 2014).

So, it can be concluded that CALL is several process which the students use computers or electronic devices with the set of instructions to teach and learn language.

CALL can play three different roles in language acquisition, while the computer can act as a tutor (e.g. for delivering instructional materials to the learner), as a stimulus (e.g. to stimulate discussion, writing, or critical thinking), or as a tool (e.g. word processors, spelling and grammar checkers, and concordances).

\section{Steps of CALL in Teaching Listening}

According to Levy, et.al, the procedure of

CALL is follows as:

1) Experience CALL as a part of preparation to train their students. It is important for students who have not learned languages through computer based activities to have that experience. This can lead to profound changes in what is trained and how the training conducted.

2) If learners are going to make informed choices regarding material and strategies for going through it, take on part of the teacher's role. It is helpful for them to have some of the same base knowledge that professional language teachers have.

3) Use a cyclical approach. Both the general concept of learner control and the mastery of specific techniques often take time and repeated exposure.

4) Allowing students to discuss their individual homework experiences in groups during the next class promotes reflection and allows them to learn from one another rather than just from the instructor.

5) Materials can be used in ways beyond those intended by the designer. For instance, any material with an accurate transcript can use for dictation practice and to support vocabulary development.

\section{The Use of CALL in Language Teaching}

Bamrung Torut suggests that the use of CALL can be divided as follows:

1) Drill and Practice

Drill and practice is to review the content/background knowledge, and to assess learner to master separate language skills (such as reading, listening, etc.).

Drill and practice consist of three steps:

1) Providing stimulus

2) Receiving active response from the learner, and

3) Giving immediate feedback

There are several types of Drill and Practice activities or exercise, such as paired associate (matching); sentence completion; multiple choice; part identification; truefalse; and short answer questions.

Well-designed Drill and Practice programs can record the learner's progress and scores and the time a student spend on each exercise. Some programs add timing features to help the learners to control their speed while practicing. Drill and Practice CALL programs in the early years focus on practicing language skills and components 
separately, for instance, vocabulary, grammar (such as irregular verbs, past tense, and articles), reading, and translation.

2) Computer as Tutor

The role of the computer as a tutor is to present to the learners the content of the lesson as text graphic, video, animation, or slides, including learning activities, drill and practice. The computer serves as a means for delivering instructional materials, The programs consist of the following stages: 1) Introduction (stating aims, background knowledge), 2) Presenting of the content, exercise and/or testing, and 3) Giving the feedback.

3) Computer as Simulation/Problem-Solving

Simulations and problem solving are used to foster analysis, critical thinking, discussion, and writing activities. The computer is not used much for tutorial purposes. The program is designed to create language interaction through problematic situations, conditions, or problems challenging the learner to solve. Many simulation programs are problem-solving games, which are both entertaining and educational in nature and purpose ("edutainment").

4) Games and Computers

CALL games and simulation gamer are similar in that both are designed motivate students to learn through entertainment. However, they are different certain ways. Simulation games always use simulations (real-life situations) in the presentation of a game, while CALL games focus on providing fun but challenging environment to the learner. Though CALL games have clear learning objectives, they are different from Tutorials and Drills and Practice. The main function of CALL games is not so much to present the language content as Tutorials do but to provide entertainment to the learner.

5) Computers as Tools for ELT Teachers and Learners

The most common tool used by teachers and learners in CALL is word processors which are tools for creating documents, for making handouts, sheets, desktop, publishing, letters, and flyers for language teaching and learning.

6) Internet Application

Computers can be connected to the internet and can incorporate interactive multimedia: text, graphics, audio, video, and animation. It can be said that the explosive growth of the internet has given new life to interactive media and CALL.

\section{CALL and Listening Skill}

The use of CALL as an approach to teaching language in general and listening skill in particular has interested many educators to do research on whether it might be an effective way in developing listening skill. In an article, it was concluded that listening skill can be more effectively developed in CALL environment as compared to traditional approaches.

The researchers stated that the results of their study confirmed the data obtained from the previously done researches about the significant effect of CALL on the improvement of listening skill. They believe that CALL materials are facilities that help learners work more effectively on listening tasks. While using CALL materials, learners get less exhausted as compared to using traditional methods.

In a study conducted by Nachoua (2012), the effect of Computer-Assisted Language 
Learning on improving students' listening skill was experimented. The researcher stated that computers are useful tools to be used in language learning classes to enhance students' performance in listening skill.

The findings of the study indicated that computer can have a significant affect role in learners' listening skill. The results of the study showed that CALL had positive effect on improvement of learners' listening skill. Findings of these related studies claimed that CALL can encourage improvement of students' ability in listening skill.

\section{RESEARCH METHODOLOGY}

To conduct this study, a quantitative method was selected. Since participants in the present research had already been enrolled in their courses and it was not possible to randomly select the learners for the sake of experiment, this study is a quasi-experimental research.

\section{Sample}

In this case, the population of this research was the seventh-grade students of SMP Negeri 3 Stabat in academic year of 2018/2019. The total students were 185 students that consisted of 6 classes. The sample of this research was 60 students. The first class was 30 students' experimental group and the second class was 30 students control group.

\section{Instruments}

The researcher used test as research instrument to collect the data. According to Djiwandono, test is an instrument of measuring a person's ability, knowledge, or performance in a given domain. It is useful to measure the students' achievement and students' progress. Besides that, it uses to evaluate the teaching learning process (2011). In this research, the researcher used listening test that adopted from Let's Talk English for Junior High School, EOS Erlangga, and English in Context. The kind of listening test was multiple choices. The researcher conducted test twice, pre-test and post-test in order to know the effect of using CALL to teach listening.

\section{Procedure}

In this study, there were two classes were randomly assigned to the experimental and control groups with 30 students in each group. In the next stage, a listening pre-test was given two groups. The pre-test was multiple choice listening skill.

After that, traditional approach to language teaching was control group and ComputerAssisted Language Learning was applied whereas in the experiment group. After two months and at the end of the experiment, a listening post-test was administered to both groups.

\section{RESULTS}

The purpose of this study was to investigate whether applying CALL approach in teaching listening skill. The obtained data from the tests were statistically analyzed through some procedure to calculate descriptive statistics required for the purpose of this study using Microsoft Excel.

the result of the test was calculated by using t-test formula.

The calculation shows that:

\begin{tabular}{lll}
\multirow{2}{*}{\begin{tabular}{l} 
Table 1 Students' Score in Pre-Test \\
\multirow{2}{*}{$\begin{array}{l}\text { Statistical } \\
\text { calculation }\end{array}$}
\end{tabular}} & $\begin{array}{l}\text { Experimental } \\
\text { group }\end{array}$ & Control group \\
\cline { 2 - 3 } & Pre-test & Pre-test \\
\hline Highest & 72 & 72 \\
\hline Lowest & 48 & 52
\end{tabular}


Table 2 Students' Score in Post-Test

\begin{tabular}{lcc}
$\begin{array}{l}\text { Statistical } \\
\text { calculation }\end{array}$ & $\begin{array}{l}\text { Experimental } \\
\text { group }\end{array}$ & Control group \\
\cline { 2 - 3 } Post-test & Post-test \\
\hline Highest & 92 & 88 \\
\hline Lowest & 80 & 56
\end{tabular}

After administering the test, the writer observed the following data which was taken from the test to the Experimental Class and Control Class.

Table 3 The Result of Pre-Test and Post Test and Deviation of Experiment Class

\begin{tabular}{|c|c|c|c|c|c|}
\hline Code & $\begin{array}{l}\text { Pre- } \\
\text { Test }\end{array}$ & $\begin{array}{l}\text { Post } \\
\text { Test }\end{array}$ & $\begin{array}{c}s X \\
\text { (Post- } \\
\text { Pre) }\end{array}$ & $s X_{I}$ & $s X 1^{2}$ \\
\hline$\sum$ & 1860 & 2520 & 660 & \multirow{2}{*}{0} & \multirow{2}{*}{920} \\
\hline$M$ & 62 & 84 & 22 & & \\
\hline
\end{tabular}

Based on the table above, it can be seen the total score of pre test is 1860 and the total of post test is 2520 , with the difference between both of the score are 660 . The average score of pre test is 62 while the average score of post test is 84 . And the standard deviation is 920 .

Table 4 The Result of Pre-Test and Post Test and Deviation of Control Class

\begin{tabular}{cccccc} 
Code & $\begin{array}{c}\text { Pre- } \\
\text { Test }\end{array}$ & $\begin{array}{c}\text { Post } \\
\text { Test }\end{array}$ & $\begin{array}{c}\boldsymbol{s} \boldsymbol{Y} \\
\text { (Post- } \\
\text { Pre) }\end{array}$ & $\boldsymbol{s} \boldsymbol{Y}_{\boldsymbol{I}}$ & $\boldsymbol{s} \boldsymbol{s \mathbf { 1 } ^ { 2 }}$ \\
\cline { 1 - 4 }$\sum_{\boldsymbol{M}}$ & 1840 & 2140 & 300 & \multirow{2}{*}{0} & \multirow{2}{*}{792}
\end{tabular}

Based on the table above, it can be seen the total score of pre test is 1840 and the total of post test is 2140 , with the difference between both of the score are 300 . The average score of pre test is 61,33 while the average score of post test is 71,33 . And the standard deviation is 792 .

From the data on the previous pages, it can be known that:
Mx: 22
My: 10
$\mathrm{Sx}_{1}^{2: 920}$
$s Y_{1}^{2:} 792$
$n \boldsymbol{X}: 30$
$n Y: 30$

The t-calculation can be calculated based on the data above, it can be known that:

$$
\begin{aligned}
& \mathrm{t}=\frac{M x-M y}{\sqrt{\left(\frac{s x^{2}+s y^{2}}{N x+N y-2}\right)\left(\frac{1}{N x}+\frac{1}{N y}\right)}} \\
& \mathrm{t}=\frac{22-10}{\sqrt{\left(\frac{920+792}{30+30-2}\right)\left(\frac{1}{30}+\frac{1}{30}\right)}} \\
& \mathrm{t}=\frac{12}{\sqrt{\left(\frac{1.712}{58}\right)\left(\frac{2}{60}\right)}} \\
& \mathrm{t}=\frac{12}{\sqrt{(29,51)(0,07)}} \\
& \mathrm{t}=\frac{12}{\sqrt{2,06}} \\
& \mathrm{t}=\frac{12}{1,43} \\
& \mathrm{t}=8,39
\end{aligned}
$$

The formula if t-test and distribution table of the t-critical value was applied in testing the hypothesis. The basis of testing hypothesis is as follows: The calculation of the scores by using $\mathrm{t}$ test for the degree of freedom (df): $58\left(\mathrm{n}_{1}+\mathrm{n}_{2}-\right.$ 2 or $30+30-2)$ at the level significance $a=$ $0,05(5 \%)$ that t-observed is 8,39 and the t-table is 1,67 . Therefore the hypothesis is accepted. In the other words, using Computer Assisted Language Learning (CALL) method affects on students' listening skill of seventh year students of SMP NEGERI 3 STABAT at academic year 2018/2019.

\section{DISCUSSION}

This study attempts to investigate the effect of applying Computer-Assisted Language Learning (CALL) as an approach to language teaching and learning on the learners' listening skill. The results of the study are consistent with the findings of all studies which claimed that CALL can encourage improvement of language skills and it can result in more learning. The 
results of the present study and all related researches that approved CALL has potentiality to develop learners' language skills including listening comprehension are quite justifiable considering the advantages that CALL offers. These advantages are in line with what Warschauer \& Healey (1998) claimed as benefits of adding computer to language instruction including:

- Multimodal practice with feedback

- Individualization

- Pair and group work

- The fun factor

- Variety in the available resources and used learning styles

- Exploratory learning

- Real-life skill-building in computer use Computer applications can help students learn a language not only in the classrooms, rather in everywhere and at any time. They can be used to review and reinforce what has been learned in the classroom. They can also be used as remedial for learners who have more difficulty compared to their classmates.

\section{CONCLUSION}

Considering the results of this study and related studies previously done, it can be concluded that proper application of CALL can be an effective approach to learners' listening skill. It can help teacher present authentic materials and teach students in the class by taking advantage of a powerful assistant. Popularity of computer technology among young learners is an influential factor that along with the numerous advantages of CALL has made this approach very attractive and constructive. A very significant feature of CALL is that it is developing increasingly by everyday progress in computer technology. Such developments give more and more potentiality to this approach that can be employed in language teaching in general and improving listening skill in particular. Therefore, integrating computer technology into the language learning process can have effective contribution to the development of language proficiency and reinforcement of language skills. It is a medium to facilitate language learning that challenges traditional methods of teaching and learning. Listening skill can be more effectively developed in CALL environment as compared to traditional approaches.

\section{REFERENCES}

Brown, H.D. 2007. Principle of Language Learning and Teaching. Prentice Hall

Djiwandono, Soenardi. (2011). Tes Bahasa Pegangan Bagi Pengajar Bahasa. Jakarta: PT Indeks

Morales, Nelson E., 2014. Use of Computer Assisted Language Learning. Education and Human Development Master's Theses. Paper 391

Nachoua, Hassina. 2012. Computer-Assisted Language Learning for Improving Students' Listening Skill. International Conference on Education and Educational Psychology (ICEEPSY 2012). 69: 11501159

Richards, J. C. (2006). Communicative Language Teaching Today. New York: Cambridge University Press. 
Rost, M. 1994. Listening in action: Activities for developing listening in language teaching. New Jersey: Prentice Hall 2002. Teaching and Researching Listening. London: Pearson Education

Sharma, Neena. 2011. Strategies for Developing Listening Skills. ELT Voices Jurnal. 1(1): 12-18

Siahaan, Sanggam. 2008. An Issue Linguistic. Yogyakarta: Graha Ilmu

Tyagi, Babita. 2013. Listening: An Important Skill and Its Various Aspects. The Criterion An International Journal in English. 1(1): 1

Warschauer, M., \& Healey, D. (1998).

Computers and Language Learning: An Overview. Language Teaching, 31, 57-71. 